\title{
HIV infection of thymocytes inhibits IL-7 activity without altering CD127 expression
}

\author{
Charlene D Young ${ }^{1,2}$ and Jonathan B Angel ${ }^{1,2,3^{*}}$
}

\begin{abstract}
Background: Thymic function is altered in HIV infection and characterized by dysregulation of the thymic epithelial network, reduced thymic output and ultimately an impaired naïve T-cell pool. The IL-7/LL-7 receptor (IL-7R) signalling pathway is critical for the maturation and differentiation of thymocytes. HIV infection is associated with a decrease in IL-7R $\alpha$ (CD127) expression and impaired CD127 signalling in circulating CD8 ${ }^{+}$T-cells; however, little is known about the effect of HIV on CD127 expression and IL-7 activity in the thymus. Therefore, the effect of in vitro HIV infection on CD127 expression and IL-7-mediated function in thymocytes was investigated.
\end{abstract}

Findings: In vitro HIV infection of thymocytes did not affect CD127 expression on either total thymocytes or on single positive CD4 or single positive CD8 subsets. However, HIV infection resulted in a decrease in the level of IL-7-induced STAT-5 phosphorylation and BCl-2 expression in unfractionated thymocytes.

Conclusion: These findings indicate that HIV infection alters IL-7 responsiveness of thymocytes by a mechanism other than CD127 downregulation and potentially explain the disruption in thymopoiesis observed in HIV infection.

\section{Findings}

Human immunodeficiency virus (HIV) infection is characterized by a loss of $\mathrm{CD} 4^{+} \mathrm{T}$-cells and a progressive loss in cytotoxic T-cell lymphocyte (CTL) function resulting in immunodeficiency. HIV infection has also been associated with impaired thymic output [1]. Examination of the thymus of HIV-infected pediatric patients reveals selective thymocyte depletion and disruption of the thymic microenvironment, which is thought to contribute to more rapid progression to AIDS [2-4]. In HIV-1 infected SCID-hu Thy/Liv mouse models, there is a depletion of intrathymic progenitor T-cells which precedes the loss of infected $\mathrm{CD}_{4}{ }^{+} \mathrm{CD} 8^{+}$thymocytes, suggesting that HIV infection interrupts thymocyte development at an early stage [5]. However, the mechanisms of disrupted thymic development by HIV have yet to be fully elucidated.

Interleukin-7 (IL-7) is a pleiotropic cytokine that is critical for several stages of thymopoiesis, maintains mature T-cell homeostasis, enhances CTL function and increases T-cell survival [6-14]. IL-7 signals through the IL-7 receptor complex (IL-7R), which is composed of two subunits: the IL-7R $\alpha$ chain (CD127), that is also shared by

\footnotetext{
* Correspondence: jangel@ohri.ca

'Ottawa Hospital Research Institute, 501 Smyth Rd., Ottawa, Canada Full list of author information is available at the end of the article
}

TSLP [15], and the IL-2R $\gamma$ chain which is shared by a number of other cytokines including IL-2, IL-4, IL-9, IL-15 and IL-21 $[7,8]$. The role of IL-7 in thymopoiesis is multifaceted, as it is critical for early stages of $\mathrm{T}$-cell development in allowing chromatin accessibility to enable T-cell receptor VDJ gene rearrangement, inducing thymocyte proliferation and maintaining thymocyte survival by upregulating the anti-apoptotic protein $\mathrm{Bcl}-2$ and downregulating the pro-apoptotic protein Bax [12,16-18]. Disrupting IL-7 signalling can result in profoundly impaired immunity as seen in patients with $\mathrm{T}^{-} \mathrm{B}^{+} \mathrm{NK}^{+}$ Severe Combined Immunodeficiency (SCID), a genetic defect that results in inactivation of the IL-7R $\alpha$ signalling pathway [19]. The importance of the IL-7 signalling complex in thymic development was confirmed in knock-out mice for both IL-7 and IL-7R. IL- $7^{-/-}$mice have a 20 fold decrease in thymic cellularity and an increase in triple negative (TN) cells, indicative of a developmental block at the TN stage [20]. The phenotype with IL-7R ${ }^{-1-}$ knockout mice is much more severe with a $90-99.99 \%$ decrease in thymic cellularity [13].

We and others have previously demonstrated that HIV infection is associated with decreased CD127 expression on circulating $\mathrm{CD} 8^{+} \mathrm{T}$-cells, and with effective antiretroviral therapy $\mathrm{CD} 127$ expression on $\mathrm{T}$-cells is partially
C Biomed Central

(c) 2011 Young and Angel; licensee BioMed Central Ltd. This is an Open Access article distributed under the terms of the Creative Commons Attribution License (http://creativecommons.org/licenses/by/2.0), which permits unrestricted use, distribution, and reproduction in any medium, provided the original work is properly cited. 
restored [21-23]. The regulation of CD127 by HIV may play a role in disease pathogenesis since the expression of CD127 has been correlated with measures of disease progression (decreased CD4 count, increased viral load, increased immune activation) [24,25]. In addition to decreased CD127 expression on T-cells, we and others have also shown that CD127 signalling is impaired in HIV infection [26-28]. Given the importance of the role of IL-7 in HIV pathogenesis and the current development of IL-7 as a therapeutic agent for HIV infection and other conditions, understanding the mechanism by which HIV impairs IL-7 activity within the thymus is of the greatest importance. The aim of this study is to evaluate the effects of HIV infection on CD127 expression and IL-7 activity in primary human thymocytes.

It has been widely reported that CD127 expression is decreased on circulating $\mathrm{CD}^{+}$and $\mathrm{CD}^{+}$T-cells of HIVinfected individuals [21-25]. We have also recently shown that in vitro infection of peripheral blood mononuclear cells (PBMC) results in decreased CD127 expression on $\mathrm{CD} 8^{+} \mathrm{T}$-cells [29]. We therefore investigated the effect of in vitro HIV infection on CD127 expression on thymocytes as a potential mechanism of HIV-induced thymic dysfunction. Thymocytes were infected in vitro with a primary isolate cs204 following previously described methods [30,31]. Briefly unfractionated thymocytes were treated with polybrene $(3 \mu \mathrm{g} / \mathrm{ml})$ (Sigma-Aldrich., Oakville, Ont) for one hour prior to infection with the dual tropic strain $\mathrm{HIV}_{\mathrm{cs} 204}$ at an M.O.I. of 0.01 or mock-infected with equivalent volumes of PBMC culture supernatants. Two hours post infection (p.i), cells were washed in phosphate buffer saline (PBS) (Invitrogen, Burlington, On), resuspended to $1.0 \times 10^{6} / \mathrm{ml}$ and co-cultured with thymic epithelial cells (TEC) (1:25) for up to 96 hours. CD127 expression on thymocytes was analysed every $24 \mathrm{~h}$ by flow cytometry. Thymocytes were stained with the following fluorochrome-conjugated monoclonal antibodies: CD3ECD (clone UCHT1), CD4-FITC (clone 13B8.2), CD8PC5 (clone B9.11), CD127-PE (clone R34.34) (all from Beckman Coulter). The distribution of the following developmental stages of $\mathrm{T}$-cell maturation was evaluated: (TN) CD3-CD4-CD8-, (immature single positive CD4 ISP4+) CD3-CD4+CD8-, (DP) CD3+/-CD4+CD8+ and (SP) CD4 + or CD8+ cells. The gating strategy for phenotype analysis is depicted in Figure 1A. There was no change in CD127 expression on unfractionated thymocytes following HIV infection over 96 hours in culture (Figure 1D). Although HIV infection did not alter CD127 expression in unfractionated thymocytes, a specific effect on individual thymic subsets may have been masked. We, therefore, infected total thymocytes and measured CD127 expression on individual thymic subsets by flow cytometry. The thymocyte subset distribution within the culture system remained unchanged over a 96 hour culture period regardless of HIV infection (data not shown). In vitro $\mathrm{HIV}_{\mathrm{cs} 204}$ infection did not alter CD127 expression on immature thymic subsets (i.e. TN, ISP4 and DP subsets; data not shown) or on the more mature single positive $\mathrm{CD}_{4}^{+}(\mathrm{SP} 4)$ or single positive $\mathrm{CD} 8^{+}$(SP8) thymocytes (Figure 1B-C).

To confirm HIV infection of thymocytes, genomic DNA was isolated from infected thymocytes as early as 24 hours and up to 96 hours p.i. Viral DNA was detectable by nested PCR targeting the gag region of HIV (Figure 2). Briefly, genomic DNA was isolated from infected thymocytes using the QIAGEN DNeasy blood and tissue kit (Qiagen, Mississauga, ON,). In the first round of PCR, DNA (1/10) was amplified with outer P24 primers $(400 \mathrm{~nm})$ forward (fwd): 5'-ATAGAGGAAGAGCAAAACAAAA-3'; reverse (rvs): 5'-GTTCCTGAAGGGTACTAGTAGT-3'. The second round PCR used $5 \mu \mathrm{l}$ of the product from the first round of PCR with inner p24 primers $(400 \mathrm{~nm})$ fwd 5'-CAAAATTACCCTATAGTG CA-3' and rvs 5'-ATGTCACTTCCCCTTGGTT CT-3'. Amplification conditions were as follows: 2 minutes at $95^{\circ} \mathrm{C},\left(94^{\circ} \mathrm{C}\right.$ for $60 \mathrm{~s}, 55^{\circ} \mathrm{C}$ for $60 \mathrm{~s}$ and $72^{\circ} \mathrm{C}$ for $\left.60 \mathrm{~s}\right)$ for 30 cycles and 7 minutes at $72^{\circ} \mathrm{C}$.

While in vitro HIV infection did not affect surface CD127 expression on thymocytes, it remains possible that in vitro HIV infection is associated with altered IL-7 signalling as has been reported in $\mathrm{CD}^{+} \mathrm{T}$-cells from HIV-infected individuals [26-28]. This was, therefore, evaluated by measuring IL-7 responsiveness of thymocytes following HIV infection. Thymocytes were infected as described above, co-cultured with TEC for up to 96 hours and stimulated with IL-7 $(1 \mathrm{ng} / \mathrm{ml})$ (SigmaAldrich Inc., Oakville Ont) $(0-10 \mathrm{ng} / \mathrm{ml})$ for 15 minutes as previously described [32]. Cells were then fixed, permeabilized, stained with Alexa Fluor ${ }^{\circledR} 488$ mouse antihuman STAT5 pY694 (BD Biosciences, San Jose, CA, USA) and analysed by flow cytometry. Thymocytes were cultured with HIV for 24 hours in order to allow sufficient time to establish infection. HIV had no impact on IL-7induced pSTAT-5 expression when evaluated 24 p.i. (Figure 3A). However, thymocytes that were infected with HIV and cultured for longer periods of time (96 hours) had lower levels of IL-7-induced pSTAT-5 compared to mock-infected controls (Figure 3B). The change in the level of STAT-5 phosphorylation was not due to changes in cell viability, since there was no significant difference in viability between HIV infected and mock infected cultures after 96 hours of culture (data not shown).

IL-7 signalling is known induce Bcl-2 expression in thymocytes [33]. In order to further determine if in vitro HIV infection alters IL-7 function, the level of IL-7induced Bcl-2 expression in HIV-infected thymocyte cultures was measured. Twenty-four hours p.i., cells 


\section{A}

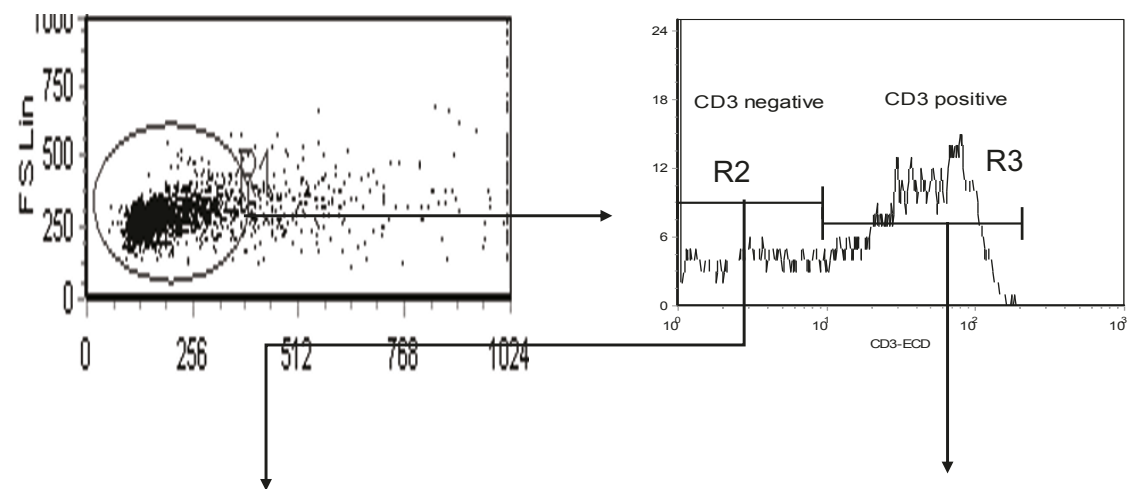

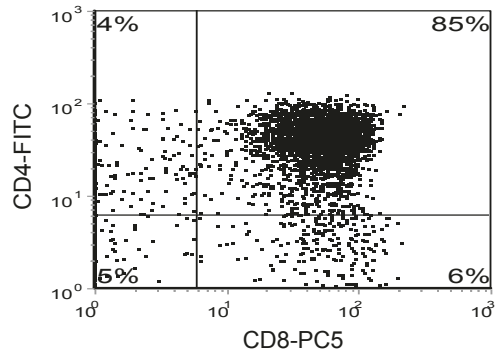

SP4

B

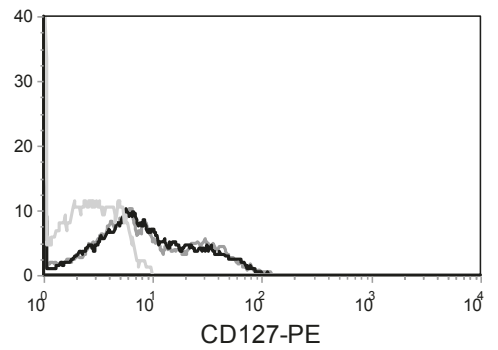

D

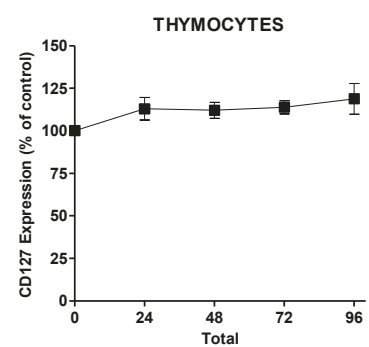

E

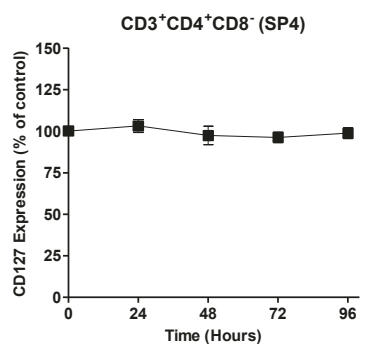

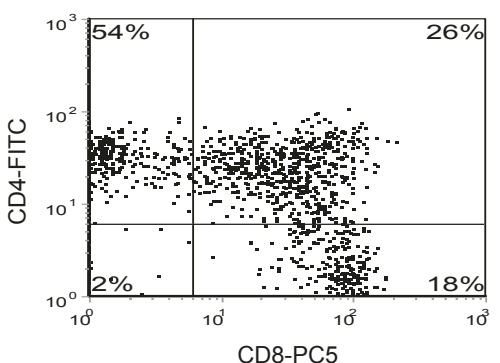

SP8

\section{C}

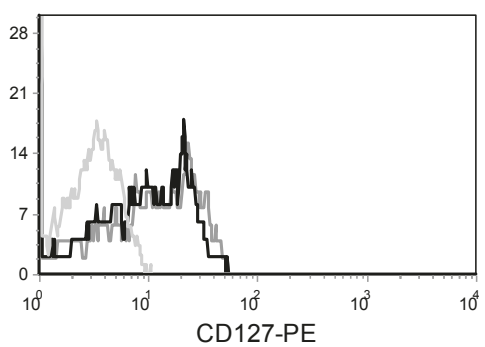

$\mathrm{F}$

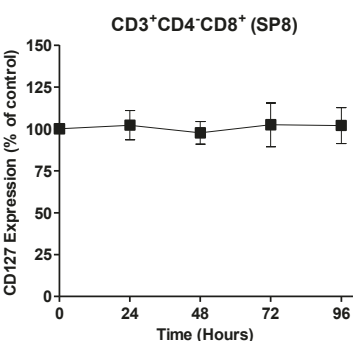

Figure 1 HIV infection does not alter CD127 expression on thymocytes. A) Unfractionated thymocytes (gate 1) were identified based on the forward scatter/side scatter profiles of live cells. The cells were then gated on either CD3- (gate 2) or $\mathrm{CD}^{+}$(gate 3 ) in a single parameter histogram. The cells in gate 2 and gate 3 were then analysed for CD4 and CD8 expression. The expression of CD127-PE (Beckman Coulter) was measured on the various subsets. Thymocytes were incubated with $\mathrm{HIV}_{\mathbf{c s 2 0 4}}$ or mock infected and co-cultured with thymic epithelial cells for up to 96 hours. Light grey lines represent isotype control, mock infected (black line) and HIV infected (dark grey line). B)SP4 subset C)SP8 subset. Summary data of CD127 expression on thymocyte measured as the proportion of cells expressing CD127 relative to mock infected cultures on D) unfractionated thymocytes, E) SP4, and F) SP8 thymic subsets. 


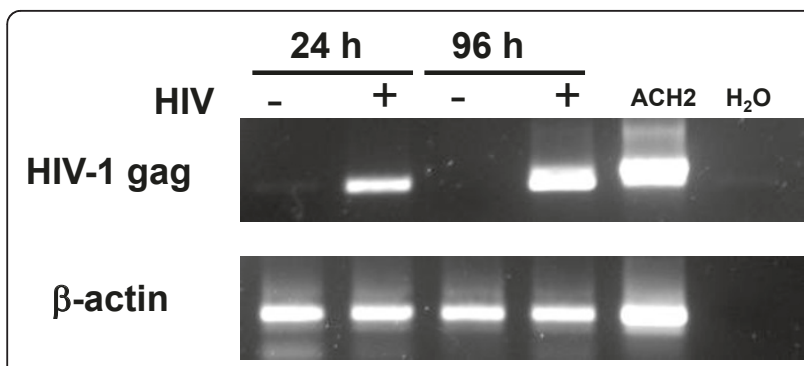

Figure $\mathbf{2}$ Thymocytes are infected by HIV. Thymocytes were incubated with $\mathrm{HIV}_{\mathrm{cs} 204}$, or mock infected and co-cultured with thymic epithelial cells. DNA was isolated from the cells following 24 hours or 96 hours p.i and the presence of HIV-1 was measured by nested PCR. As a positive control, DNA was isolated from ACH2 cells, and water was used as a negative control in the PCR reaction. Results are representative of 3 separate experiments.

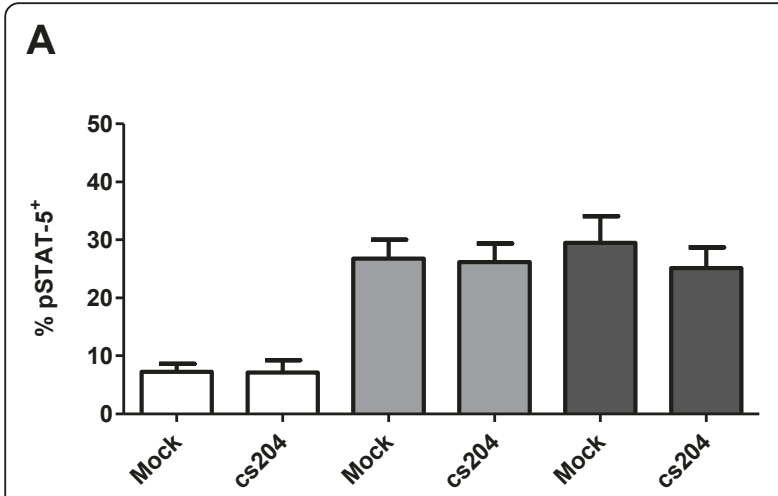

B

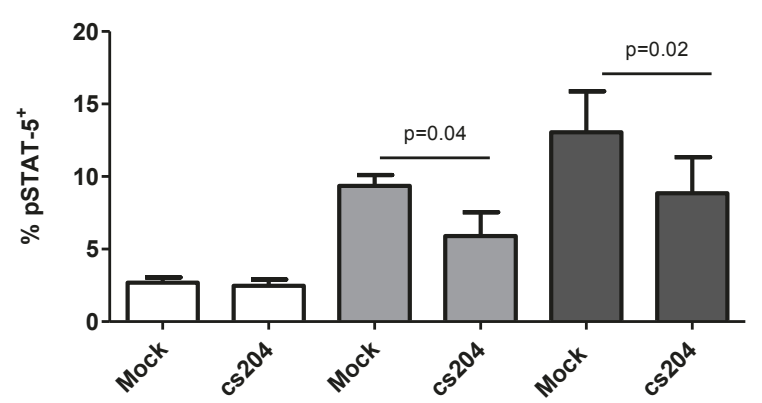

$\square$ Control

IL-7 $1 \mathrm{ng} / \mathrm{ml}$

$\mathrm{IL}-710 \mathrm{ng} / \mathrm{ml}$

Figure 3 The effect of in vitro HIV infection on IL-7-induced STAT-5 phosphorylation in thymocytes. Thymocytes were incubated with $\mathrm{HIV}_{\mathrm{cS} 204}$ or mock infected and co-cultured with thymic epithelial cells. Following co-culture for A) 24 hours or B) 96 hours, thymocytes were stimulated with IL-7, and STAT-5 phosphorylation in the total thymocyte population was measured by intracellular flow cytometry. were washed and stimulated with IL-7 (0-10 ng/ml) for 48 hours as previously established for optimal Bcl-2 induction by IL-7 [34]. Cells were then fixed, permeabilized, stained with Bcl-2-FITC (BD Bioscience) and analysed by flow cytometry. As expected, 48 hours of stimulation with IL-7 resulted in increased Bcl-2 expression in unfractionated thymocytes. In vitro HIV infection resulted in a small but non-significant decrease of constitutive Bcl-2 expression. Consistent with what was seen with the effect on STAT-5 activation, infection with $\mathrm{HIV}_{\mathrm{cs} 204}$ inhibited the ability of IL-7 to induce Bcl2 expression in thymocytes (Figure 4).

IL-7 also signals through the PI3K pathway leading to cell proliferation and glucose uptake [35]. Thymocytes were infected for up to 96 hours, serum starved for 2 hours and stimulated with IL-7 (10 ng/ml) for 1 hour. Cells were lysed, and proteins were separated on an $8 \%$ SDS-polyacrylamide gel and transferred to a nitrocellulose membrane. Activation of the PI3K pathway was visualised by probing the membranes with antibodies for phosphorylated AKT (Cell Signalling, Danvers, MA). In contrast to its effect on STAT-5 and Bcl-2, HIV infection did not affect the ability of IL-7 to induce PI3K posphorylation (data not shown).

The importance of IL-7 and its effect on thymopoiesis are unequivocal. Disrupting this pathway leads to a block in thymopoiesis and the arrest of T-cell development. IL-7 signals through both the JAK/STAT and PI3K pathways to mediate cell survival, proliferation and differentiation [35,36]. HIV infection both in vitro and in vivo is associated with reduced CD127 on $\mathrm{CD}^{+}{ }^{+} \mathrm{T}$-cells and $\mathrm{CD}^{+} \mathrm{T}$ cells [21-25]. We have, however, demonstrated that in vitro HIV infection of thymocytes does not affect the surface expression of CD127 on thymocytes. The decreased $\mathrm{CD} 127$ expression on $\mathrm{CD}^{+} \mathrm{T}$-cells following

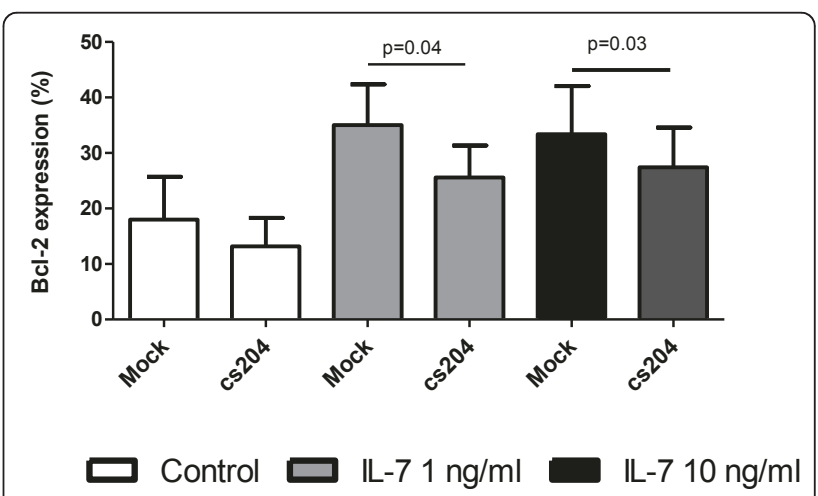

Figure 4 The effect of HIV infection on the ability of IL-7 to induced $\mathrm{Bcl}-2$ expression in thymocytes. Thymocytes were incubated with $\mathrm{HIV}_{\text {cs204 }}$ or mock infected and co-cultured with thymic epithelial cells for 24 hours. After 24 hours of culture, thymocytes were stimulated with IL-7 for 48 hours, and Bcl-2 expression was measured by intracellular flow cytometry. 
in vitro HIV infection appears to be due to soluble factors released in the culture microenvironment by PBMCs [29]. Any such factors present in PBMC cultures may not be present in thymocyte/TEC co-cultures, potentially accounting for the differential effect of HIV on CD127 expression.

Although decreased IL-7 activity can result from decreased receptor expression, a block in the IL-7 signalling pathway may also result in altered IL-7 activity. This phenomenon has been reported for IL-2 activity where $\mathrm{CD}^{+}{ }^{+} \mathrm{T}$-cells and $\mathrm{CD}^{+}{ }^{+} \mathrm{T}$-cells from $\mathrm{HIV}^{+}$individuals are less responsive to IL-2 compared to those from healthy controls which has been attributed to a block in the JAK/ STAT pathway $[37,38]$. The results in this report indicate that IL-7-induced STAT-5 phosphorylation and Bcl-2 expression are impaired in thymocyte cultures infected with $\mathrm{HIV}_{\mathrm{cs} 204}$ while no effect on CD127 expression was observed. This suggests that HIV infection results in a block in the IL-7 pathway that occurs independent of its effect on CD127 expression. These data support the findings by Vranjkovic et al., which demonstrated reduced IL-7 responsiveness in CD127-expressing CD8 ${ }^{+} \mathrm{T}$-cells from $\mathrm{HIV}^{+}$patients. In that study, isolated $\mathrm{CD} 8^{+} \mathrm{CD} 127^{+}$ cells from $\mathrm{HIV}^{+}$individuals had lower levels of STAT-5 phosphorylation following IL-7 stimulation when compared to those from uninfected controls [26]. Such a block in IL-7 signalling has also been observed in other disease states. For example, $\mathrm{CD} 4^{+}$and $\mathrm{CD} 8^{+} \mathrm{T}$-cells isolated from breast cancer patients are less responsive to IL-7, as measured by STAT-5 phosphorylation [39].

HIV may affect thymocyte function by altering the viability of the cells, consequently lowering the output of functional T-cells from the thymus $[2,3,40,41]$. In support of this hypothesis, our data show that HIV infection interferes with the ability of IL-7 to induce Bcl-2 expression. A similar block in the ability of IL-7 to upregulate Bcl-2 expression was reported in a study in which $\mathrm{CD} 4^{+} \mathrm{T}$-cells from $\mathrm{HIV}^{+}$individuals had lower levels of $\mathrm{Bcl}-2$ expression following IL-7 stimulation when compared to those from healthy controls. That study found no correlation between CD127 expression of $\mathrm{CD} 4^{+} \mathrm{T}$ cells and IL-7 responsiveness, suggesting that the block in IL-7 activity was independent of the level of CD127 expression [42].

The exact mechanism by which HIV interferes with the IL-7 signalling pathway has yet to be determined, however our results indicate that binding of HIV to the cell surface is likely insufficient to mediate this effect since there was no impact of HIV on IL-7 activity within the first 24 hours of infection. Rather, our data demonstrated that the cells need to be infected for longer periods of time (72-96 hours) for the effect of HIV to be observed, suggesting that the mechanism of inhibition might require the production of specific cellular or viral factors.
In summary, we demonstrated that HIV infection alters IL-7 activity in thymocytes independent of CD127 expression suggesting a potential mechanism by which HIV infection interrupts thymic output and contributes to immune deficiency.

\section{Acknowledgements}

We appreciatively acknowledge Dr. G. Maharajh and staff at the Children's Hospital of Eastern Ontario for providing the thymus samples. We are grateful to Dr. Angela Crawley for critical review of the manuscript. This research was supported by grants to J.B.A from the Ontario HIV Treatment Network (Grant \#ROGB131), the Canadian Institutes of Health Research (Grant \#HOP84649) and the Canadian Foundation for AIDS Research (Grant \# 019014). C.Y. is a recipient of a CIHR studentship and J.B.A. is an OHTN Career Scientist.

\section{Author details}

1Ottawa Hospital Research Institute, 501 Smyth Rd., Ottawa, Canada.

${ }^{2}$ Department of Biochemistry, Microbiology and Immunology, University of Ottawa, 450 Smyth Rd., Ottawa, Canada. ${ }^{3}$ Division of Infectious Diseases, Ottawa Hospital-General Campus, 501 Smyth Rd.Ottawa, Canada.

\section{Authors' contributions}

CY participated in the design of the study, performed the experiments and wrote the manuscript. JA conceived of the study, participated in the design of the study and helped to draft and edit the manuscript.

\section{Competing interests}

The authors declare that they have no competing interests.

Received: 15 March 2011 Accepted: 16 September 2011

Published: 16 September 2011

\section{References}

1. Gaulton GN: Viral pathogenesis and immunity within the thymus. Immunol Res 1998, 17:75-82.

2. Kourtis AP, Ibegbu C, Nahmias AJ, Lee FK, Clark WS, Sawyer MK, Nesheim S: Early progression of disease in HIV-infected infants with thymus dysfunction. N Engl J Med 1996, 335:1431-1436.

3. Rosenzweig M, Clark DP, Gaulton GN: Selective thymocyte depletion in neonatal HIV-1 thymic infection. Aids 1993, 7:1601-1605.

4. Joshi W, Oleske JM, Saad S, Gadol C, Connor E, Bobila R, Minnefor AB: Thymus biopsy in children with acquired immunodeficiency syndrome. Arch Pathol Lab Med 1986, 110:837-842.

5. Stanley SK, McCune JM, Kaneshima H, Justement JS, Sullivan M, Boone E, Baseler M, Adelsberger J, Bonyhadi M, Orenstein J, et al: Human immunodeficiency virus infection of the human thymus and disruption of the thymic microenvironment in the SCID-hu mouse. J Exp Med 1993, 178:1151-1163.

6. Fry TJ, Connick E, Falloon J, Lederman MM, Liewehr DJ, Spritzler J, Steinberg SM, Wood LV, Yarchoan R, Zuckerman J, et al: A potential role for interleukin-7 in T-cell homeostasis. Blood 2001, 97:2983-2990.

7. Fry TJ, Mackall CL: Interleukin-7: from bench to clinic. Blood 2002, 99:3892-3904.

8. Hofmeister R, Khaled AR, Benbernou N, Rajnavolgyi E, Muegge K, Durum SK: Interleukin-7: physiological roles and mechanisms of action. Cytokine Growth Factor Rev 1999, 10:41-60.

9. Tan JT, Dudl E, LeRoy E, Murray R, Sprent J, Weinberg KI, Surh CD: IL-7 is critical for homeostatic proliferation and survival of naive T cells. Proc Natl Acad Sci USA 2001, 98:8732-8737

10. Okazaki H, Ito M, Sudo T, Hattori M, Kano S, Katsura Y, Minato N: IL-7 promotes thymocyte proliferation and maintains immunocompetent thymocytes bearing alpha beta or gamma delta T-cell receptors in vitro: synergism with IL-2. J Immunol 1989, 143:2917-2922.

11. Schluns KS, Kieper WC, Jameson SC, Lefrancois L: Interleukin-7 mediates the homeostasis of naive and memory CD8 T cells in vivo. Nat Immunol 2000, 1:426-432.

12. Hare KJ, Jenkinson EJ, Anderson G: An essential role for the IL-7 receptor during intrathymic expansion of the positively selected neonatal T cell repertoire. J Immunol 2000, 165:2410-2414. 
13. Peschon JJ, Morrissey PJ, Grabstein KH, Ramsdell FJ, Maraskovsky E, Gliniak BC, Park LS, Ziegler SF, Williams DE, Ware CB, et al: Early lymphocyte expansion is severely impaired in interleukin 7 receptordeficient mice. J Exp Med 1994, 180:1955-1960.

14. Sudo T, Nishikawa S, Ohno N, Akiyama N, Tamakoshi M, Yoshida H: Expression and function of the interleukin 7 receptor in murine lymphocytes. Proc Natl Acad Sci USA 1993, 90:9125-9129.

15. Pandey A, Ozaki K, Baumann H, Levin SD, Puel A, Farr AG, Ziegler SF, Leonard WJ, Lodish HF: Cloning of a receptor subunit required for signaling by thymic stromal lymphopoietin. Nat Immunol 2000, 1:59-64.

16. Durum SK, Candeias S, Nakajima H, Leonard WJ, Baird AM, Berg L, Muegge K: Interleukin 7 receptor control of T cell receptor gamma gene rearrangement: role of receptor-associated chains and locus accessibility. $J$ Exp Med 1998, 188:2233-2241.

17. Huang J, Muegge K: Control of chromatin accessibility for V(D)J recombination by interleukin-7. J Leukoc Biol 2001, 69:907-911.

18. Kang J, DiBenedetto B, Narayan K, Zhao H, Der SD, Chambers CA: STAT5 is required for thymopoiesis in a development stage-specific manner. $J$ Immunol 2004, 173:2307-2314.

19. Puel A, Ziegler SF, Buckley RH, Leonard WJ: Defective IL7R expression in T $(-) \mathrm{B}(+) \mathrm{NK}(+)$ severe combined immunodeficiency. Nat Genet 1998, 20:394-397.

20. Moore TA, von Freeden-Jeffry $U$, Murray $R$, Zlotnik A: Inhibition of gamma delta T cell development and early thymocyte maturation in IL-7 -/mice. J Immunol 1996, 157:2366-2373.

21. Colle JH, Moreau JL, Fontanet A, Lambotte O, Joussemet M, Delfraissy JF, Theze J: CD127 expression and regulation are altered in the memory CD8 T cells of HIV-infected patients-reversal by highly active antiretroviral therapy (HAART). Clin Exp Immunol 2006, 143:398-403.

22. MacPherson PA, Fex C, Sanchez-Dardon J, Hawley-Foss N, Angel JB: Interleukin-7 receptor expression on CD8(+) T cells is reduced in HIV infection and partially restored with effective antiretroviral therapy. $J$ Acquir Immune Defic Syndr 2001, 28:454-457.

23. Paiardini M, Cervasi B, Albrecht $H$, Muthukumar A, Dunham R, Gordon S, Radziewicz H, Piedimonte G, Magnani M, Montroni M, et al: Loss of CD127 expression defines an expansion of effector CD8+ T cells in HIV-infected individuals. J Immunol 2005, 174:2900-2909.

24. Koesters SA, Alimonti JB, Wachihi C, Matu L, Anzala O, Kimani J, Embree JE, Plummer FA, Fowke KR: IL-7Ralpha expression on CD4+ T lymphocytes decreases with HIV disease progression and inversely correlates with immune activation. Eur J Immunol 2006, 36:336-344.

25. Rethi B, Fluur C, Atlas A, Krzyzowska M, Mowafi F, Grutzmeier S, De Milito A, Bellocco R, Falk Kl, Rajnavolgyi E, Chiodi F: Loss of IL-7Ralpha is associated with CD4 T-cell depletion, high interleukin-7 levels and CD28 downregulation in HIV infected patients. Aids 2005, 19:2077-2086.

26. Vranjkovic A, Crawley AM, Patey A, Angel JB: IL-7-dependent STAT-5 activation and CD8+ T cell proliferation are impaired in HIV infection. $J$ Leukoc Biol 2011, 89:499-506.

27. Camargo JF, Kulkarni H, Agan BK, Gaitan AA, Beachy LA, Srinivas S, He W, Anderson S, Marconi VC, Dolan MJ, Ahuja SK: Responsiveness of T Cells to Interleukin-7 Is Associated with Higher CD4(+) T Cell Counts in HIV-1Positive Individuals with Highly Active Antiretroviral Therapy-Induced Viral Load Suppression. J Infect Dis 2009, 199:1872-1882.

28. Benoit A, Abdkader K, Sirskyj D, Alhetheel A, Sant N, Diaz-Mitoma F Kumar A, Kryworuchko M: Inverse association of repressor growth factor independent-1 with CD8 T cell interleukin (IL)-7 receptor [alpha] expression and limited signal transducers and activators of transcription signaling in response to IL-7 among [gamma]-chain cytokines in HIV patients. Aids 2009, 23:1341-1347.

29. A Komsic-Vranjkovic EF, MacPherson P, Angel J: Differential regulation of IL-7 receptor (CD127) on CD8+ $\mathrm{t}$ cells: implications for HIV immunopathogenesis. Canadian Journal of Infectious disease and medical microbiology 2005, 16(Supplement SA).

30. Chambers KA, Parato KG, Angel JB: Active cellular infection of myeloid cells is required for HIV-1-mediated suppression of interleukin-12 p40 expression. Cell Immunol 2002, 215:120-132.

31. Chene L, Nugeyre MT, Guillemard E, Moulian N, Barre-Sinoussi F, Israel N: Thymocyte-thymic epithelial cell interaction leads to high-level replication of human immunodeficiency virus exclusively in mature CD4 (+) CD8(-) CD3(+) thymocytes: a critical role for tumor necrosis factor and interleukin-7. J Virol 1999, 73:7533-7542.
32. Crawley AM, Faucher S, Angel JB: Soluble IL-7R alpha (sCD127) inhibits IL7 activity and is increased in HIV infection. J Immunol 2010, 184:4679-4687.

33. Jiang Q, Li WQ, Hofmeister RR, Young HA, Hodge DR, Keller JR, Khaled AR, Durum SK: Distinct regions of the interleukin-7 receptor regulate different Bcl2 family members. Mol Cell Biol 2004, 24:6501-6513.

34. Crawley AM, Katz T, Parato K, Angel JB: IL-2 receptor gamma chain cytokines differentially regulate human CD8+CD127+ and CD8+CD127T cell division and susceptibility to apoptosis. Int Immunol 2009, 21:29-42.

35. Barata JT, Silva A, Brandao JG, Nadler LM, Cardoso AA, Boussiotis VA: Activation of PI3K is indispensable for interleukin 7-mediated viability, proliferation, glucose use, and growth of T cell acute lymphoblastic leukemia cells. J Exp Med 2004, 200:659-669.

36. Pallard C, Stegmann AP, van Kleffens T, Smart F, Venkitaraman A, Spits H: Distinct roles of the phosphatidylinositol 3-kinase and STAT5 pathways in IL-7-mediated development of human thymocyte precursors. Immunity 1999, 10:525-535.

37. Kryworuchko M, Pasquier V, Keller H, David D, Goujard C, Gilquin J, Viard JP, Joussemet M, Delfraissy JF, Theze J: Defective interleukin-2-dependent STAT5 signalling in CD8 T lymphocytes from HIV-positive patients: restoration by antiretroviral therapy. Aids 2004, 18:421-426.

38. David D, Bani L, Moreau JL, Treilhou MP, Nakarai T, Joussemet M, Ritz J, Dupont B, Pialoux G, Theze J: Regulatory dysfunction of the interleukin-2 receptor during HIV infection and the impact of triple combination therapy. Proc Natl Acad Sci USA 1998, 95:11348-11353.

39. Vudattu NK, Magalhaes I, Schmidt M, Seyfert-Margolis V, Maeurer MJ: Reduced numbers of IL-7 receptor (CD127) expressing immune cells and IL-7-signaling defects in peripheral blood from patients with breast cancer. Int J Cancer 2007, 121:1512-1519.

40. Douek DC, McFarland RD, Keiser PH, Gage EA, Massey JM, Haynes BF, Polis MA, Haase AT, Feinberg MB, Sullivan $J$, et al: Changes in thymic function with age and during the treatment of HIV infection. Nature 1998, 396:690-695.

41. Sodora DL, Milush JM, Ware F, Wozniakowski A, Montgomery L, McClure HM, Lackner AA, Marthas M, Hirsch V, Johnson RP, et al: Decreased levels of recent thymic emigrants in peripheral blood of simian immunodeficiency virus-infected macaques correlate with alterations within the thymus. J Virol 2002, 76:9981-9990.

42. Colle JH, Moreau JL, Fontanet A, Lambotte O, Delfraissy JF, Theze J: The correlation between levels of IL-7Ralpha expression and responsiveness to IL-7 is lost in CD4 lymphocytes from HIV-infected patients. Aids 2007, 21:101-103.

doi:10.1186/1742-4690-8-72

Cite this article as: Young and Angel: HIV infection of thymocytes inhibits IL-7 activity without altering CD127 expression. Retrovirology $20118: 72$.

\section{Submit your next manuscript to BioMed Central and take full advantage of:}

- Convenient online submission

- Thorough peer review

- No space constraints or color figure charges

- Immediate publication on acceptance

- Inclusion in PubMed, CAS, Scopus and Google Scholar

- Research which is freely available for redistribution

Submit your manuscript at www.biomedcentral.com/submit
C Biomed Central 